\title{
The epistemology of the value of aqidah akhlaq education in Biyanglala poetry book by Abdul Wachid B.S. (A semiotic study)
}

\author{
Metros Prihatin a, 1*, Heru Kurniawan ${ }^{\text {b, } 2 \text {, Adi Purnomo }}{ }^{c, 3}$ \\ a PGMI, Pascasarjana, IAIN Purwokerto \\ b Tarbiyah, IAIN Purwokerto \\ ${ }^{c}$ PAI, Pascasarjana, IAIN Purwokerto \\ 1201763010@mhs.iainpurwokerto.ac.id*; heru_I982@yahoo.com; 19I766003@mhs.iainpurwokerto.ac.id \\ *201763010@mhs.iainpurwokerto.ac.id
}

\begin{tabular}{ll}
\hline Article's information \\
\hline History: & \\
Submitted & $:$ 23 Januari 202I \\
Revised & $: 8$ April 202I \\
Published & $:$ 30 April 202I \\
\hline
\end{tabular}

Kata kunci:

Akidah, akhlak, pendidikan, Biyanglala, Semiotik

\begin{abstract}
Artikel ini bertujuan untuk menganalisis dan mendeskripsikan nilai pendidikan akidah akhlak dalam kumpulan puisi Biyanglala karya Abdul Wachid B.S.. Metode yang digunakan dalam penelitian ini adalah metode penelitian kualitatif studi pustaka, teknik pengumpulan data dilakukan dengan mempelajari bacaan berupa catatan kuliah, buku, literatur dan peraturan yang berkaitan dengan masalah yang diteliti. Objek penelitian ini adalah buku puisi Biyanglala. Untuk menganalisis dan mendeskripsikan nilai pendidikan aqidah akhlaq dalam buku puisi, digunakan konsep semiotika Michael Riffaterre. Berdasarkan hasil penelitian, ditemukan bahwa buku puisi Biyanglala karya Abdul Wachid BS mengandung nilai pendidikan aqidah akhlaq, yaitu pada puisi "Ketika Lima Puluh Tahun", "Hujan Pagi" dan "Stasiun Sebuah Pertemuan ". Puisi "Ketika Lima Puluh Tahun" adalah model puisi untuk nilai keimanan dan puisi "Hujan Pagi" adalah model puisi untuk nilai-nilai moral. Puisi "Ketika Lima Puluh Tahun" memberikan pesan penyerahan atau penyerahan "Aku" kepada Tuhan. Betapa murninya tawakal itu harus disandarkan kepada Yang Maha Kuasa dan Maha Pengampun, Allah Swt. Puisi Hujan Pagi mengandung makna nilai-nilai moral seperti tanggung jawab, prasangka baik dan syukur atas nikmat dan rahmat yang Allah berikan. Puisi "Stasiun Sebuah Pertemuan" merupakan puisi yang mengandung nilai tauhid tentang asma wa shifat. Puisi "Suara" berisi pesan untuk selalu jujur.
\end{abstract}

\section{ABSTRACT}

Key word:

Aqidah Akhlaq Education

Biyanglala

The purpose of this paper is to analyze and describe the value of aqidah akhlaq education in Abdul Wachid B.S.'s poems especially in Biyanglala. The method used in this research was qualitative research method of library research where the data collection technique is carried out by studying the reading in the form of lecture notes, books, literature and regulations related to the problem under study. The object of research in this paper is the Biyanglala poetry book. To analyze and describe the value of aqidah akhlaq education in the poetry book, the writer uses Michael Riffaterre's semiotics. According to the results of the study, the writers found out that Biyanglala poetry book by Abdul Wachid B.S.'s contained the value of aqidah akhlaq education, namely in the poetry "Ketika Lima Puluh Tahun", "Hujan Pagi" and "Stasiun Sebuah Pertemuan". The poem "Ketika Lima Puluh Tahun" is a poetry model for the value of faith and the poem "Hujan Pagi" is a poetry model for moral values. The poem "Ketika Lima Puluh Tahun" gives a message of surrender or submission of the "I" to God. How pure tawakal must be relied on to the Almighty and the All- and Oft-Forgiving, Allah SWT. The poem "Hujan Pagi" implies moral values such as responsibility, good prejudice and gratitude for the blessings and grace that Allah has given. The poem "Stasiun Sebuah Pertemuan" is a poem that contains monotheistic value about asma wa shifat. The Poem "Suara" contains a message to always be honest. 


\section{Introduction}

Derived from the occurrence of incredibly fast developing culture, the culture which was initially created by human to facilitate and promote welfare has been perceived and developed in the wrong way, opposite to their humanity aspect. This might result in human becoming individual who is too busy with their working hours as if they are only packed with mechanical things.

Human has become a one dimensional being who sees anything from its worldly aspect. Human, instead, is a being with physical and spiritual dimensions as explained in the words of Allah in Al-Hajj verse 46:

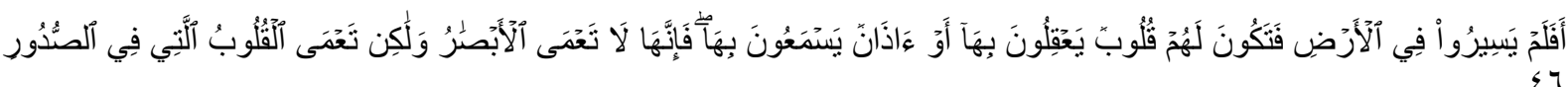

"Have they not travelled throughout the land so their hearts may reason, and their ears may listen? Indeed, it is not the eyes that are blind, but it is the hearts in the chests that grow blind."

If human is to fixated on worldly matters only, they will experience alienation and their life will feel lonely. Therefore, it is important to refresh them, to restore their human side. The human side of humanity means restoring human from being machine-like or human who doesn't believe in God. Considering everything is facilitated by culture, human need to reflect on themselves again based on their prophetic roles.

To restore their human dimension which has been torn by modern life, human needs to build religion mindset aside from the worldly ones. One of the possible solutions to the problem is through literature. Friedrich Schiller says that literature can become a kind of game to balance the mental aspect of a human (in Agus Wibowo, 2013: 20). Consequently, literature is important as the framework of this research. Accordingly, the writers want to identify the aqidah akhlaq (moral and faith) education using a literature work, Biyanglala poetry book by Abdul Wachid B.S.

This research studies literary works because of their dual function, borrowed from Horatius, dulce et utile which means beautiful and useful (Ed. Wachid B.S., 20I4: 374). The writers chose the poems of Abdul Wachid B.S. among other Indonesian writers because there are not many of them who have both spiritual and human dimensions. The other writers in Indonesian modern poetry who have both dimensions are KH. A. Mustofa Bisri, KH. D. Zawawi Imron. Acep Zamzam Noor dan Abdul Wachid B.S. (batch 2000 in Indonesian Literature, edited by Korrie Layun Rampan).

There is a lot of research studying literature and also both the literary works and personality of Abdul Wachid B.S. One of which is research by Faiz Adittian titled "Pendidikan Spiritual dalam Buku Puisi Rumah Cahaya dan Nun Karya Abdul Wachid B.S" who divides spiritual education in the poetry of Abdul Wachid B.S. into three steps, takhalli, tahali, and tajalli.

In another research titled "Pendidikan Karakter dalam Buku Puisi Hyang karya Abdul Wachid B.S. (Analisis Profetisme Kuntowijoyo)", he analyzed character education value, transcendence value, liberation value, and humanization value in the poetry compiled in the book. The understanding of prophetic literature derived from the noble characters of Prophet Muhammad PBUH, including sidiq, amanah, tabligh, and fathanah.

Heru Kurniawan's research in his book titled "Mistisisme Cahaya" also discusses Rumah Cahaya poetry book as its subject. He explored the mysticism of light in the poetry using metaphorical and symbolic analysis

Another research in Arif Hidayat's book, "Aplikasi Teori Hermeneutik dan Wacana Kritis" (Arif Hidayat, 2012), discusses the creative writing process of Abdul Wachid B.S., his subjective views in his poetry, and his interview production and its delivery strategy.

In another research on Abdul Wachid B.S. by Ahmad Dahlan (Ahmad Dahlan, 2018) titled "Kritik Sosial dalam Sajak Alang-alang karya Abdul Wachid B.S. (Kajian Hermeneutika Paul Ricoeur)", additionally, discusses criticism towards the government who lies to people, as well as criticism towards people who commit riot and destruction.

The next is research titled "Nilai-nilai Pendidikan Profetik dalam Buku Puisi Yang karya Abdul Wachid B.S'. Its object is the prophetic education values, while its subject is the poetry book by Abdul Wachid B.S and how relevant the prophetic education is in daily life.

Another research titled "Feminisme dalam Puisi Abdul Wachid B.S." was conducted by Teguh Trianton. His research shows that the poem "Istri yang melati" and "Wanita yang mengandung Sembilan Purnama" raise the issue of domestic violence and polygamy in which both belong to the most discussed issues by the feminism movement (Trianton, 2009). In the same research, he also mentions that Abdul Wachid B.S., as the writer of both the poetry, is a male feminist. 
From various existing research above, the writer tries to find a gap related to the poetry of Abdul Wachid B.S. and fill it in. To identify the aqidah akhlaq education value in the poetry of Abdul Wachid B.S. the writer used structural semiotic theory. The studied media were poems in which their first reading resulted ungrammatical arrangement (Rapika et.al. 20I5: I4). To interpret such ungrammatical form in the poetry, a perspective based on a sign analysis, semiology-semiotics is needed.

From the background above, this research aims to analyze and describe the aqidah akhlaq education value in Abdul Wachid B.S. especially in Biyanglala poetry book. The aqidah akhlaq education value is expected to remind the readers about the importance of strong faith (aqidah) towards the God and good morale (akhlaq) towards other creatures.

\section{Methods}

This research used a qualitative method called library research in which the data were collected through examining reading resources such as lecture notes, books, literatures, and regulations related to the problem being examined (Ajat Rukajat, 2018: 27). The subject of this research was Biyanglala poetry book by Abdul Wachid B.S. while its object was focused on the epistemology of akhlaq education values.

To obtain aqidah akhlaq education value in Biyanglala poetry book, the writer used Michael Riffaterre's semiotic theory which considers the social phenomenon and culture as symbols. Semiotics also study systems of rules which have meanings.

The meaning-making of a literary work according to Riffaterre's semiotic theory are:

I. Indirect expression in poetry-literary work caused by displacing of meaning, distorting of meaning, and creating of meaning

2. Heuristic and Hermeneutic

3. Matrix, Model, and Variant

4. Hypogram. (Riffaterre, 1978: 2)

The first step in analyzing the poetry using Riffaterre's semiotics was heuristic reading. Heuristic reading is reading in the mimesis reading step based on a culture system and convention. After that, there was retroactive reading by doing literature convention, called as hermeneutic reading (Adittian, 2019: 58)

\section{Results and Discussions}

\section{Aqidah and Akhlaq in Islam}

Aqidah is derived from Arabic word 'aqd" which means strong and firm bond, one which cannot be separated from another. Aqidah can also be defined as promise and strengthen the oath. Additionally, it can also be defined as to tightly bind (Shafik and Bakar, 2009: 93). Aqidah also means urging one's heart to justify the existence of God, to stay pure from doubt (Solihin, 2020: 85). In addition, Aqidah is also interpreted a belief in their heart, promised by the mouth, and practiced in actions (Rofiah, 2016: 56). According to the definitions above, it can be concluded that Aqidah is the faith in God inside human's heart, which is not only a belief in their heart, but also promised by the mouth, and practiced in everyday actions.

Many believes that Aqidah is the same as Tauhid. According to Ade Wahidin (via Anshory, Bukhari dan Bachtiar, 2019: 3I3), Tauhid is the interpretation of the oneness of Allah in one's actions and the negation of the existence of other worshipped deities. Tauhid, as stated in the Qur'an, is like the main root which gives energy to the trunk, branches and leaves of life. In like manner, it is also like the upstream which lead the direction and quality of the water in the river of life. It begins from tauhid, activities, and education (Kadar, 2013:2). Tauhid is the faith on the oneness of the Essence of Allah. Not only believing in the existence of Allah, the one who create the universe and whatever inside, Tauhid also means believing in Allah's provisions, including the characters, asma', and af al (Kholiq, 2018: 26).

Tauhid is seen as identical with Aqidah because both lead to the faith to Allah, but the difference between both lies on the meaning of bond in Aqidah, the commitment to form a bond and adhere to it. Affirming a commitment can affirm the continuity of the understanding and appreciate continually the substance and expression of faith. Tauhid inclines to oneness interpretation. The goal of tauhid is the guidance process to develop and decide on the ability of human in getting to know the oneness of Allah SWT. On the other hand, aqidah is a strong belief or faith, binding strongly and firming, of which according to its term, it also means a firm and certain faith without any doubt to someone who make an either right or wrong decision (Idzni, 2018: 28).

Etymologically, akhlaq is the plural form of khuluq which means good characters, tempers, behavior, or conduct. The word akhlaq also comes from the same root as khalaqa which means the act of creating. Additionally, 
the word akhlaq also has the same root as the word khalik which means the creator, makhluk which means to be created, and khalq which means creation. That they have the same root word implies that inside the word akhlaq there is the definition of the creation of the unity between the creator (khalik) and the creation (makhluk) (Ilyas, 20I4: I).

\section{Abdul Wachid B.S.}

Abdul Wachid B.S. was born on October 7, 1966 in Bluluk, Lamongan. Abdul Wachid B.S. got his first education in SD I Bluluk in his village. He continued to a junior high school in Babat, SMP Negeri I Babat. He then moved to Yogyakarta when he began studying at a senior high school level in SMA Negeri Agromuyo, After that, he continued to study at the Faculty of Law in Universitas Cokroaminoto, and at the same time he also studied Indonesian Literature in the Faculty of Cultural Sciences. Universitas Gadjah Mada. He also got his Master degree at Universitas Gadjah Mada. Later, he got his doctoral degree after finishing his doctoral program at Universitas Sebelas Maret Surakarta.

Abdul Wachid B.S. has published some poetry books, some of them are: Rumah Cahaya, Ijinkan Aku Mencintaimu, Tunjammu Kekasih, Beribu Rindu Kekasihku, Yang, Kepayang, Hyang, and Nun. He also wrote other works beside poetry, such as: Sastra Melawan Slogan, Religiositas Alam: dari Surealisme ke spiritualisme D. Zawawi Imron, Sastra Pencerahan, etc. Biyanglala is his $9^{\text {th }}$ poetry book which published in August 2020.

\section{Poetry "Ketika Lima Puluh Tahun"}

ada yang mulai tertanggal

dari tanggal hariku, dan di hatimu

engkau cemasskan

gigiku yang tidak sanggup tinggal

kau merasakan saban bangun tidur

ada yang mulai pegal linu di persendian

kakiku dan di urat tubuhmu, terasa asam urat

nadimu yang kadang berdentang kencang

seperti lonceng gereja yang

mengingatkan pada ucapan "selamat tidur"

abadi, sungguh aku ingin menidurkan

kepalaku yang penuh impian dan pertempuran

di pangkuan dan hatimu yang

maha lembut sekaligus maha kuat

aku sudah membuktikan tarikan demi tarikan

antara surga, dan neraka tidak mampu lantakkan

pangkuan dan hatimu yang

selalu ada cerita, lebih lima puluh tahun

akan banyak lagi "kau aku" yang tertanggal

tetapi akan semakin menjadi yang tertinggal

seperti setiap selesai shalat

kurebahkan kepalaku

ke pangkuanmu, mengekal

hatimu mendenyutkan nadiku

di dalam pelukan

terasa kesakitan hidup

kau aku

saling menyembuhkan

Yogyakarta, I8 March 2018 (Abdul Wachid B.S., 2020: 23) 


\section{The interpretation of surrendering oneself to Allah as a tauhid value in poetry "Ketika Lima Puluh Tahun"}

This poetry has its uniqueness where the title can be parts of each verse when they are read. When (I am) fifty years old there is something dated in my days and in your heart. You (often) worried about my teeth which cannot stay.

You feel, every time you wake up, there is aches and pains in the joints, the muscle of your body, it is gout. Your pulse beats faster like a Church's bell, reminding you the eternal "good night" word. Really, I want to lie down my head, full of dreams and battles, in your lap, Maha lembut (The Most Gentle) and Maha kuat (The Almighty)

I have proved (that) pull by pull between heaven and hell cannot destroy your lap and heart, wherein stories for more than fifty years. There will be more "you I" left out, yet will be even more left out just like lying down my head onto your lap every after shalat, until I'm becoming eternal.

Your heartbeat (also) beats my pulse (when I am) in your embrace. (Though) the life feels hurt, you (and) I heal each other.

Heuristically, the reading of the poetry "Ketika Lima Puluh Tahun" is like narrating the love life of a couple in their fifties. How the "I" has solicitudes about his falling teeth, joint pain, and many other, while the "you" is someone who always accompanying, strengthening and healing each other.

To get a deeper interpretation of the poetry, a second step of reading, the hermeneutic, should be conducted. The third verse of "Ketika Lima Puluh Tahun" expresses that the pulse of the "you" reminds the "I" of an eternal good night greeting, so that the "I" wants to lie his head on the lap of the "you" which is Maha lembut (The Most Gentle) and Maha kuat (The Almighty).

The word Maha in Indonesian means more than the usual. Maha is usually put before the characters and attributes of God. The word Maha differentiates God from the creatures. Allah Maha Kuasa means there is no one more omnipotent than Allah's authority. Islam believes that only God (Allah) who has the absolute authority in everything (Pohan, 2018: 8). Therefore, the use of Maha in the fourth verse creates multiple interpretations of the "you" in which it can be referred as a lover or as God.

With the multiple interpretations of the "you", the word "menidurkan" (put to sleep) can also have another interpretation. It can be a symbol of surrendering, like how a servant surrenders to his God. Surrendering to The Most Gentle and The Almighty God is in line with Q.S. Ali Imran verse I59-I60.

The model in the poetry "Ketika Lima Puluh Tahun" is the word "menidurkan" which represents surrendering to the God like how human sleeps, surrendering completely. The first variation is in "pangkuan dan hatimu" and "pelukan". Pangkuan dan hatimu (your lap and heart) in the "you" is the symbol of God's power authority of which the lap shows the attributes of The Most Gentle as well as The All-Strong. In like manner, Allah is the Almighty and The All- and Oft-Forgiving, because the power of Allah is "Maha", human as his creature should surrender to Allah.

The second variation is "ke pangkuanmu, mengekal hatimu mendenyutkan nadiku" or "in your lap, perpetuating your heart, pulsating my pulse". Mengekal or perpetuating proves that Allah is eternal. Allah is $A I$ awwal, and Allah is Al-Akhir.

In "hatimu mendenyutkan nadiku", there is a message that human is actually the manifestation of the image of God. Accordingly, hatimu (your heart) in the "you" (God) can mendenyutkan nadiku (pulsate my pulse) in the "I" (human). It means that the life and death of human is within the power of Allah.

Matrix of the poetry "Ketika Lima Puluh Tahun" is the surrendering of a servant symbolized by in God's embrace. It also expresses anxiety during the old age (in the fifties) when human hasn't approached the lap of Allah. The "I" feels empty whenever his tauhid level is far from perfect. Even the anxiety intensifies whenever the body ages and the joint get inflamed. No one can give him comfort like except the grace of Allah.

\section{Poem "Hujan Pagi"}

hujan pagi tidak pernah

menghalangi kau aku menepati janji

hujan pagi hanya menambah

hangat yang menjalar ke akarakar darah

hujan pagi memberinya orkestrasi pertemuan

antara desah dan resah

menjadi lirik dan lagu yang 
menumbuhkan pohon dan bunga

yogyakarta, March 2019(Abdul Wachid B.S., 2020: 40)

\title{
Akhlaq Principles in the poem "Hujan Pagi"
}

Before the hermeneutic reading, heuristic reading is carried out first. The heuristic reading of the poem is described in the next paragraph.

Morning rain(indeed) has never kept you and me from keeping your promise. It (instead) warms up along the roots of the blood. (moreover) morning rain carries (the wave) of orchestration (whenever) there is an encounter between sighs and restlessness. (that orchestration) can be the lyrics and song which can grow flowers.

After the heuristic reading, hermeneutic reading is carried out. The hermeneutic reading is described in the next paragraphs.

The first to third verses begins with "hujan pagi" or morning rain. This repetition gives an emphasis to the "I" is the rain pouring in the morning. In the hermeneutic reading, reader should never believe in the literal meaning of the text. At glance "Hujan Pagi" or morning rain gives an impression of describing the enthusiasm of a lover in the morning. However, there is actually a lot of symbolism of akhlaq in the poetry.

In the first verse, morning rain never keep you and me keeping the promise. A promise is a responsibility which should be paid off by the person bearing the responsibility.

It is one of the indicator of being responsible and keeping promises (Suharman \& Mukminan, 20I7: 7). There are a lot of responsibilities in the morning, such as teacher going to teach at school, students going to study at school, doctor going to the hospital to treat the patient, and many other occupations begin in the morning. The rain should not hider or become a reason not to keep the promise or responsibilities. It is related to akhlaq as being responsible is one of the noble akhlaq.

The rain is disliked by people, especially, in the morning is seen in a positive light. In the second verse, the morning rain is said to spread the warmth along the root of blood. The "I" felt the increasing warmth inside his blood because of the rain. This shows that something perceived as negative can be perceived positive when someone change his point of view a little. To change negativity into positivity, one can try to be grateful for God's favor.

In the third and fourth verses, morning rain gives orchestration between sighs and restlessness into lyrics and sing which grow trees and flowers. As rain grows beautiful flowers and shade trees, noble akhlaq also grows harmonious and beautiful relationship among humans.

The model in the poetry "Hujan pagi" is the hujan pagi or morning rain itself which is viewed in a more positive point of view as a blessing from God. The variants are "menepati janji", "menambah hangat", and "menumbuhkan pohon dan bunga". The first variant begins with "menepati janji”. Keeping a promise is one of the noble akhlaq, while breaking a promise is a characteristic of a munafiq or hypocrite, a despicable character. The value of akhlaq taken from this variant is keeping a promise and responsibilities of the tasks given to each person.

The second variant "menambah hangat" or "increasing warmth". The message conveyed by "I" in this variant is that good prejudice will bring in a good thing. Rain in the morning usually is undesirable, especially during working days. However, with good prejudice, rain can even bring warmth.

The third variant is "menumbuhkan pohon dan bunga" or "growing trees and flowers". One noble akhlaq should lead to another noble akhlaq. For example, like the second variant where noble akhlaq leads to another good akhlaq, it continues leading to other noble akhlaq.

The matrix in this poem is how the noble akhlaq conveyed implicitly like responsibilities and good prejudice which leads to another good thing. By changing the point of view, something negative can change into something positive. The hypogram in the poem "Hujan Pagi" is the scenery of rain pouring in the morning. Rain is the blessing from Allah which can be the life source of living things (Mu'jizat, 2018: 99).

\author{
Poem "Stasiun Sebuah Pertemuan" \\ ada banyak jalan pilihan \\ menuju musim hujan yang \\ menunggu aku menunggu di tepian jendela \\ aku menembusnya dengan payung \\ atau ke dataran musim kemarau \\ dimana aku dan debu samalah diterbangkan \\ oleh angin dan ketidak berdayaan
}




\author{
dahaga kasihsayang tak terbilang \\ atau aku kian demam di simpang jalan hatimu yang \\ hakim agung dari hari kemarin itu tibatiba bisa \\ mengetokkan palu bahwa \\ aku harus disalibkan seperti isa \\ tetapi aku memilih jalan musim di luar musim \\ tidak semmua kebenaran diungkapkan bahasa yang \\ pasti aku tidak takut kepada bayang-bayang \\ apalagi cuma dunia dan kemegahan \\ sekalipun terbaca di semua halaman buku \\ di segalapersimpangan dan perjumpaan \\ sedari bangkubangku kuliah kau aku dulu \\ di setiap pelukan dan perpisahan: pandanglah..... \\ ke depan keberduaan kau aku adalah \\ perjalanan indah hati nurani \\ dan aku tidak akan pernah berhenti menyusuri \\ sebuah jalan panjang tanpa akhir menuju hatimu \\ tersebab engkaulah jalan \\ sekaligus tujuan itu sendiri \\ dari stasiun ini ke stasiun lain \\ ke balik cakrawala
}

yogyakarta, 3 June 20I8 (Abdul Wachid B.S., 2020: 28)

\title{
The aqidah value in the poem "Stasiun Sebuah Pertemuan"
}

The heuristic reading of the poem is: (indeed) there are many roads (and) choice towards raining season which makes me wait on the window framw or pierce through with umbrella or towards the land of dry season wherein I and dust are both flown by wind and (also) uncertainty.

(either) the thirst (for) (countless) affection or I (who) become more feverish at the intersection of the road of your heart which is (like) the Supreme Judge. Since yesterday (that judge) suddenly can knocks the hammer that I have to be crucified like (the prophet) Isa.

But I choose the season road outside the season. Not all of the truth is conveyed by language. For certain, I won't be afraid of the shadows, let alone the mere world and grandeur. Even if (all mu actions can be) read in all (life) book pages, (either) at every intersections and meetings since (when I sat) in the seats of university class, you and I used to be in the (each other's) embrace and partings.

(and then) look ahead! Because of our being together is a beautiful journey (corresponding to) of the conscience. And, I won't stop going down the long endless road towards your heart because you are the road and the destination itself. (the journey of live such as) from railway station to railway station (until finally it ends) to beyond the horizon,

The next is the hermeneutic reading. The poem "Stasiun Sebuah Pertemuan" is like narrating the "I" who is in the railway station waiting to go to the next station. Furthermore, the poem also implies the aqidah value. In the first verse, "ada banyak pilihan" or there are a lot of choice symbolizes that there are various paths (thariq) to God. Accordingly, which way is the correct one should not be debatable as people have their own paths. In the same verse, there is a metaphor "menunggi di tepian jendela" or "menembus dengan payung" which illustrate the path chosen by each person has its own truth.

The freedom of living being to choose its path to God is the prove of God's love and affection in getting people to know each other. Because the almighty is God, his creature is helpless (in comparison). In the second verse, the existence of human is symbolized through debu or dust which is like being flown by the wind. To survive, human will need the help and the only one, unmeasurable love from God. In the verse a tauhid form of asma wa shifat, Ar-Rahman. 
Aside from Ar-Rahman, one of Allah's characters and attributes is also illustrated in the third verse. AlHakim, Allah can punish anyone committing bad deeds like "menyalibkan manusia seperti Isa" or crucifying human just like Isa. Allah's punishment, certainly, imposed only after the prior deliberation of the notes written in the next verse "terbaca di semua halaman buku".

The goal of our life is towards Allah. It is from Allah and towards Allah. "pandanglah ke depan" or "look ahead" beckons readers to focus on the goal. On the other hand, to look ahead can also reflect the choice of going the straight path. In a journey, the most chosen path is, certainly, the straight path. Thus, in poem "Stasiun Sebuah Pertemuan" the "I" tries to look ahead. In Quran Surah al-Fatihah, it mentions Ihdina Shiratal Mustaqim.

In the last verse, there is another tauhid symbol of asma wa shifat. "Engkaulah jalan sekaligus tujuan itu sendiri" or "you are the path and the destination itself" symbolize the asma of Allah, al-Awaldan al-Akhir. Human's life is in the time or era created by Allah, but Allah is not bind by time. There is no one creates the beginning of Allah and no one ends it.

The model of the poem "Stasiun Sebuah Pertemuan" is "jalan" or "path" which symbolize that human is like going on journey in life. The variants of the poem are "ada banyak jalan pilihan", "diterbangkan oleh angin dan ketidak berdayaan", "terbaca di semua halaman buku", and "jalan sekaligus tujuan".

The model in the poem "Stasiun Sebuah Pertemuan" which symbolize human ho is in his life is (like) having a journey. The variants in the poem "Stasiun Sebuah Pertemuan" are "ada banyak jalan pilihan”, "diterbangkan oleh angin dan ketidak berdayaan”, "terbaca di semua halaman buku”, and "jalan sekaligus tujuan”.

The first variant is "ada banyak jalan pilihan". It implies that there are many ways in practicing a religion. The chosen way can be different from one person to another. The difference related to the choice should not be something to be argued. Also, there is a famous saying, "Ada banyak jalan menuju Roma" or "There are a lot of path to Rome" indicates that a way is the medium used to reach a goal. The goal of every movie is Allah, but the path they take is unique to one another.

The second variant is "diterbangkan oleh angin dan ketidakberdayaan" or "flown by wind and helplessness". It symbolizes the helplessness side of a human with dust, and it is relevant. In front of Allah, human, even the king, have no power compared to the power of Allah.

The third variant is "adalah terbaca di semua halaman buku" or red in every page of the books. It refers to the charities and deeds notes down by Raqib and Atid. Later those notes will be counted and shall be displayed, whether it is the good or bad deeds which has more amount than the other. The last variant is "jalan sekaligus tujuan" or "the path is also the goal". "engkaulah jalan sekaligus tujuan itu sendiri" symbolizes the asma of Allah, al-Awal and al-Akhir. It is how human is created by God in a certain time or era. However, Allah is not bound by time. There is no one creates the beginning of Allah and no one ends it.

The Matrix of the poem "Stasiun Sebuah Pertemuan" is several asma and characteristic of Allah implied in the poem, such as al-Hakim, al-Awal, and al-Akhir. The hypogram in the poem is the "I" who enjoys the journey from one station to another, just like the journey towards Allah SWT.

\section{Poem "Suara”}

kau akan membeli berapa

pada suaraku?

bayangkan

bila tibatiba suaramu lenyap

kepada siapa, di plaza mana

kau akan mencari pengganti

suaramu yang

menghilang?

suara itu terbungkam

oleh salam tempel di bibir

sebelum sempat berkata salam

Purwokerto, I7 april 2019 


\section{The Akhlaq value in the poem "Suara Ibu"}

The first step is heuristic reading of the poem. Pembacaan pertama untuk menganalisis sajak "Suara" adalah dengan pembacaan heuristik terlebih dahulu.

You buy my voice (at) how much (the price)? (try to) imagine if your voice quiet downt. (If so) in which plaza will you go searching for your lost voice?

The voice (can be) linked by salam tempel which block the mouth (so that it is not voiced). (The voice will vanish because of salam tempel) before they even greet each other.

The next is the hermeneutic reading. The poem "Suara" has multiple interpretations as the word "suara" or voice itself has various meaning. It can be interpreted as the sound from one's mouth, or the number of voters in a general election. When reading the date of the poem, it is the date around when the general election was held or a vote.

The important point in the poem "Suara" is not the big number of suara, but the honesty in getting them in a general election. The first verse the "I" asks "kau akan membeli berapa pada suaraku?" or how much are you willing to pay for my suara? this question word have different meaning depending on how it is read. The meaning of the first verse can be about the bargaining of the price of suara of the "I". It can also be implied from the question that the interlocutor of the "I" cannot but the suara of the "I".

The next verse affirms that it is intended by the "I" that the "I" will not let the "you" buy his "suara". The "I" asks the "you" what if the voice of the "you" lyrics becomes quite. The "you" cannot give his "suara" to someone, as well as buy someone else's "suara" in a plaza. The question of the "I" is a satire to how "suara" cannot be bought*.

In the last verse, the "I" explains that one becomes quiet after "salam tempel". The leaders who get a certain degree of prominence in the government gives many people "salam tempel". The leaders who get their position in the government by using "salam tempel" Many do not hear the suara of people asked for their suara in the general election.

Accordingly, the poem "Suara" gives the candidate of future leader should always be honest. The leaders should be look for "suara" in an honest way. People should also not get tempted by the salam tempel given, so that the elected government leaders will listen to people's "suara" or voice.

The model in the poem "Suara" is "suara" which have double meaning, the suara or voice as sounds uttered by the mouth and the voice meaning vote in a general election. The variant is "mencari pengganti suara" and "salam tempel". The first variant "mencari pengganti suara" explains that the vote one has accumulated using money, he will only look for a way to look for the money lost during the campaign or even to gain his own profit when he is finally in the government.

The second variation is "salam tempel". It is a symbol of bribery in the election. In the poem of "suara", money can silence a voice. The voiceless voice is the people whose aspiration is not heard.

The matrix of the poem "Suara" is honesty. The trade of "suara" will not give a good impact after the general election ends. The hypogram of the poem "Suara" is that the "I" refuses to give his "suara" to the "you" who gives him salam tempel.

\section{Conclusion}

In Biyanglala poetry book by Abdul Wachid B.S., there are four poems containing the aqidah akhlaq education value, in the poem "Ketika Lima Puluh Tahun", "Hujan Pagi" and "Stasiun Sebuah Pertemuan". The poem Ketika Lima Puluh Tahun is the model poem for the aqidah value model, while the poem "Hujan Pag" is the poem akhlaq value model. The poem "Ketika Lima Puluh Tahun" gives a message on surrendering the "I" to God, on how pure tawaqal should be based on the Almighty and The All- and Oft-Forgiving God, Allah SWT. The poem "Hujan Pagi" implies the akhlaq values, such as responsibilities, good prejudice, and grateful of the blessings and grace given by Allah. The poem "Stasiun Sebuah Pertemuan" is the poetry model containing taujid value of asma wa shifat. The poem "Suara" implies the honesty aspect of a general election which should be applied by all parties involved. The poem "Suara" contains a message to always be honest. Therefore, all of the four poems mentioned is used as a reference for aqidah akhlaq learning in our education institution.

\section{Acknowledgements}

The most heartfelt gratitude to Dr. Abdul Wachid B.S., S.S., M.Hum. (the writer of Biyanglala) for the permission and support given to us to study Biyanglala poetry book. 


\section{References}

Adittian, F. (2018). Pendidikan Karakter dalam Buku Puisi Hyang karya Abdul Wachid B.S. i(Analisis Profetisme Kuntowijoyo dalam Jurnal Ta'dib: Jurnal Pendidikan Islam.

Adittian, F. (2020). "Pendidikan Spiritual dalam Buku Puisi Rumah Cahaya dan Nun karya Abdul Wachid B.S." dalam Tesis. Purwokerto: IAIN Purwokerto.

Anshory, M.I., Bukhari, D.S., Bachtiar, T.A. (2019). "Pemurnian Aqidah dalam Pendidikan Islam: Telaah atas Kitab Bonang karya Sunan Bonang” dalam Jurnal Edukasi Islami: Jurnal Pendidikan Islam.

Dahlan, A. (2018). Kritik Sosial dalam Sajak Alang-alang karya Abdul Wachid B.S. (Kajian Hermeneutika Paul Ricoeur) dalam Skripsi. Purwokerto: IAIN Purwokerto.

Hidayat, A. (2012). Aplikasi Teori Hermeneutika dan Waca Kritis. Purwokerto: Penerbit iSTAIN iPress.

Idzni, N. (2018). Nilai-nilai Pendidikan Tauhid Perspektif Empat Imam Mazhab Fiqih dalam skripsi. Lampung: UIN Raden Intan Lampung.

Ilyas, Y. (20I4). Kuliah Akhlaq. Yogyakarta: LPPI.

Kadar, M.Y. (2013). Tafsir Tarbawi. Jakarta: Amzah.

Kholiq, M.N. (2018). Nilai-Nilai Pendidikan Tauhid dalam Kitab Jawahirul Kalamiyah karya Syekh Thahir bin Saleh al-Jazairi” dalam Skripsi. Salatiga: Institut Agama Islam Negeri (IAIN) Salatiga.

Mu'jizat, M.J. (2018). "Proses Turunnya Hujan dalam al-Qur'an (Suatu Analisis Tafsir Tahlili terhadap QS. alRum/30: 48)” dalam skripsi. Makassar: Universitas Islam Negeri Alauddin Makassar.

Pohan, Z. R. H. (2018). "Titik Analisis Marx dan Foucault pada Kuasa dan Jalan Penindasan atas Kematian Tuhan” dalam skripsi. Banda Aceh: UIN Ar-Raniry Banda Aceh.

Rampan, K.L. (2000). Angkatan 2000 dalam Sastra Indonesia. Jakarta: Grasindo.

Rapika, Saman, S., \& Syahrani, A. (2015). Pemaknaan Kata-kata Mantra Sembodoh (Penakluk) Masyarakat Melayu Banjarsari Kecamatan Kendawangan Kakabupaten Ketapang: Kajian Semiotik. Jurnal Pendidikan dan Pembelajaran Khatulistiwa, 4(4).

Riffaterre, M. (1978). Semiotic of Poetry. Bloomington: Indiana University.

Rofiah, N.H. (2016). "Desain Pengembangan Pembelajaran Aqidah Akhlaq di Perguruan Tinggi” dalam Jurnal Fenomena.

Rukajat, A. (2018). Pendekatan Penelitian Kuantitatif. Yogyakarta: Deepublish.

Shafik, S.A., Bakar, N.S.A. (2009). "Tauhid Membina Keutuhan Aqidah Islam” dalam Jurnal Islam dan Masyarakat Kontemporati.

Solihin, R. (2020). “Aqidah dan Akhlaq dalam Perspektif Pembelajaran PAI di Madrasah Ibtidaiyah” dalam Jurnal Kependidikan Dasar Islam Berbasis Sains.

Surahman, E., \& Mukminan, M. (2017). Peran guru IPS sebagai pendidik dan pengajar dalam meningkatkan sikap sosial dan tanggung jawab sosial siswa SMP. Harmoni Sosial: Jurnal Pendidikan IPS, 4(I).

Wachid B.S., A. (2002). Analisis Struktural Semiotik Puisi Surealistis Religius D. Zawawi Imron. Yogyakarta: Cinta Buku

------. (2020). Biyanglala. Yogyakarta: Cinta Buku.

Wibowo, A. (2013). Pendidikan Karakter Berbasis Sastra. Yogyakarta: Pustaka Pelajar. 